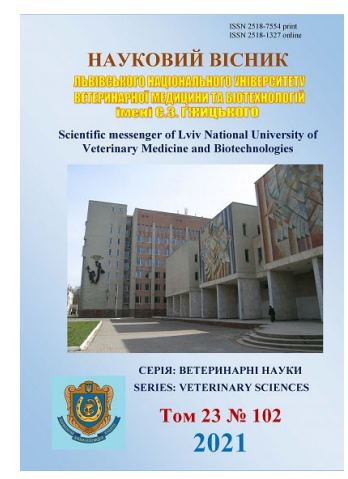

Науковий вісник Яьвівського національного університету ветеринарної медицини та біотехнологій імені С.3. Гжицького. Серія: Ветеринарні науки

\author{
Scientific Messenger of Lviv National University \\ of Veterinary Medicine and Biotechnologies. \\ Series: Veterinary sciences
}

UDC 636.8.09:619.9:579.882(477.53-25)

\title{
Epizootological features and clinical manifestation of cat chlamydiosis in Poltava
}

\author{
O. O. Peredera, I. V. Lavrinenko, R. V. Peredera, I. A. Zhernosik, G. M. Pogorelova \\ Poltava State Agrarian Academy, Poltava, Ukraine
}

Article info

Received 14.04.2021

Received in revised form 17.05.2021

Accepted 18.05.2021

Poltava State Agrarian Academy, Skovorody Str., 1/3, Poltava, 36003, Ukraine.

Tel.: +38-095-748-02-58

E-mail:lenavet26@ukr.net
Peredera, O. O., Lavrinenko, I. V., Peredera, R. V., Zhernosik, I. A., \& Pogorelova, G. M. (2021). Epizootological features and clinical manifestation of cat chlamydiosis in Poltava. Scientific Messenger of Lviv National University of Veterinary Medicine and Biotechnologies. Series: Veterinary sciences, 23(102), 99-104. doi: 10.32718/nvlvet10215

The article presents epizootological data and clinical signs of feline chlamydia in Poltava. According to the results of studies in 2018-2020, a wide spread of chlamydia infection among cats in the city of Poltava was established. The largest number of the studied cats, were pedigree or crossbred. There was no explicit clear seasonality, but a greater number of cases of respiratory diseases were recorded in the autumn-winter period of the year. In the structure of infectious diseases during the research period, chlamydia mono-infection was registered in $68 \%$ of cats, association of chlamydia with infectious rhinotracheitis in $18.5 \%$, kalitsivirus infection in $8.6 \%$, with panleukopenia in $4.9 \%$. The greatest number of the registered cats had acute and subacute course of chlamydia. In the acute course, there was an increase in temperature, oppression and refusal to eat. In the majority of cases of acute, subacute and associated chlamydia, the structures of the eye were damaged. Conjunctivitis, keratitis, chemosis, uveitis, third eyelid inflammation, changes in the shape of the pupil developed. A Sphynx breed cat showed signs of acute chlamydial arthritis with pronounced inflammatory edema. The latent course was accompanied by abortions, which were mainly registered in young cats. Animals older than four years more often showed stillborn and weak kittens. The main clinical signs of chlamydia in kittens born from sick cats were eye lesions: swelling of the conjunctiva, its reddening and secretion of a significant amount of brown purulent exudate with the viscosity of the catarrh and as a consequence of eyelid adhesion and complications as ankyloblepharon or symblepharon. Submandibular and other lymph nodes in the head area were significantly enlarged. Often pus dried up near the mouth or nostrils. Pus crusts accumulated in the nasal cavity and prevented breathing. Gastrointestinal tract disorders were observed in some cases. Part of the affected litter died within the first three days after birth. Neonatal chlamydia was more often manifested by conjunctivitis, keratitis, panophthalmitis and growth retardation. On the second or third day after birth, the kittens showed weakness and lack of appetite. In two cases of neonatal chlamydia, bronchopneumonia developed. When chlamydia and infectious rhinotracheitis were associated, the structures of the eye were affected in all cases. These lesions could be different and depended on the stage of the infectious process.

Key words: cats, chlamydia, prevalence, conjunctivitis, keratitis.

\section{Епізоотологічні особливості та клінічний прояв за хламідіозу котів у місті Полтава}

О. О. Передера, І. В. Лавріненко, Р. В. Передера, І. А. Жерносік, Г. М. Погорелова

Полтавська державна аграрна академія, м. Полтава, Украӥна

У статті наведено епізоотологічні дані та клінічні ознаки за хламідіозу котів у м. Полтава. За результатами досліджень 2018-2020 року встановлено значне поширення хламідійної інфекиії серед котів у м. Полтава. Найбільша кількість досліджуваних котів, були безпорідними або помісними. Вираженої чіткої сезонності не відмічалось, але більшу кількість випадків респіраторних хвороб реєстрували в осінньо-зимовий період року. У структурі інфекційних захворювань за дослідний період хламідійну моно інфекцію реєстрували у 68 \% котів, асоціацію хламідіозу з інфекційним ринотрахеїтом у 18,5\%, каліцівірусною інфекцією - 8,6 \%, 
з панлейкопенією - 4,9\%. Найбільша кількість зареєстрованих котів мали гострий та підгострий перебіг хламідіозу. За гострого перебігу відбувалося підвищення температури, пригнічення та відмова від їжі. У більшості випадків гострого, підгострого та асоційованого хламідіозу пошкоджувалися структури ока. Розвивалися кон'юнктивіти, кератити, хемози, увеїти, запалення третьої повіки, зміни форми зіниці. У кота породи “Сфінкс” виявляли ознаки гострого хламідійного артриту з вираженим запальним набряком. Латентний перебіг супроводжувався абортами, які здебільшого реєстрували у молодих кішок. У тварин старие чотирьох років частіше виявляли мертвонароджених та слабких кошенят. Основними клінічними ознаками хламідіозу кошенят, щзо народилися від хворих кішок, було ураження очей: набряки кон'юнктиви, ї̈ почервоніння та виділення значної кількості коричневого гнійного ексудату із в'язкістю катару $і$ як наслідок злипання повік та ускладнення у вигляді анкілоблефарону чи сімблефарону. Підщелепні, та інші лімфатичні вузли в діляниі голови суттєво збільшувалися. Часто гній засихав біля ротового отвору, ніздрів. Гнійні кірочки накопичувалися в носовій порожнині та заважали дихати. В окремих випадках спостерігали розлади илунково-кишкового тракту. Частина ураженого приплоду гинула впродовж перших трьох діб після народження. Неонатальний хламідіоз найчастіше проявлявся кон'юнктивітами, кератитами, панофтальмітами та затримкою росту. На другу-третю добу після народження у кошенят проявлялася слабкість, відсутність апетиту. У двох випадках за неонатального хламідіозу розвивалася бронхопневмонія. За асочійованого прояву хламідіозу та інфекційного ринотрахеїту, в усіх випадках вражалися структури ока. Ці ураження могли бути різними, залежали від стадії інфекційного процесу.

Ключові слова: коти, хламідіоз, поширення, кон'юнкивіти, кератити.

\section{Ветуп}

Згідно 3 дослідженнями Мартинюк О. Г. (2015), хламідійні інфекції характеризуються широким різноманіттям клінічних проявів, тому хламідіози тварин надзвичайно поширені та можуть мати різні асоціативні складові (Halánová et al., 2011; Martynyuk, 2015). Це, у першу чергу, пов'язано з унікальними біологічними характеристиками збудника, його швидкою адаптацією в організмі тварин, тривалою персистенцією, можливістю генералізації інфекції та вибірковістю уражень окремих систем чи органів (Stavisky et al., 2012; Wu et al., 2013).

Хламідії мають широкий ареал існування: їх виділяють від домашніх і диких ссавців, птахів, численних видів плазунів, рептилій та риб (Ksonz et al., 2010; Ksonz, 2012; Sachse et al., 2015).

Мікроорганізми захоплюють нові ніші, завдяки своїм біологічним властивостям. Одне із них - здатність утворювати L-форми, які здатні зберігатися роками, не проявляючи клінічних ознак. Інший фактор - це численні можливості щодо пристосувань в організмі тварин. 3 одного боку, хламідії паразитують, як правило, у епітеліальних тканинах. Це призводить до масштабних уражень органів дихальної системи, статевих органів, шлунково-кишкового тракту, суглобів, нервової системи, у склад яких входять епітеліальні тканини (Romanyshyna et al., 2012; Galatyuk et al., 2016; Lisova \& Savchenko, 2017). Ще одне пристосування, що вартує уваги - це безмежні адаптивні процеси. Адже для більшості збудників не існує міжвидових меж, вони легко адаптуються до тварин нових видів, людини, різних видів птахів. Хламідії використовують різноманітні шляхи передачі: аліментарні, трансплацентарні, аерогенні і контактні (Ksonz, 2012; Galatyuk et al., 2016). Тому, поширення, біологічні особливості і навіть морфологічні варіації хламідій детально вивчаються (Pantchev et al., 2010; Lisova \& Savchenko, 2017).

Коти - одні із найбільш сприйнятливих до хламідіозу тварини. Згідно із окремими статистичними даними, збудник хламідіозу був виявлений у понад $40 \%$ досліджуваних котів в Німеччині, Франції Сполучених Штатах Америки, Швейцарії. Дещо нижчі показники наявності збудника у досліджуваних котів встановлені у Великобританії (21 \%), Бельгії - (24 \%).
Канаді (36 \%). У Японії хламідії виявляли у 10-12\% котів. Можливо, значну роль відіграє висока щільність популяції тварин даного виду та наявність резервуара збудника: синантропних гризунів і птиці в природі. Тому проблема хламідіозів тварин, особливо котів, має вагомі медико-соціальні наслідки (Sykes, 2005; Pantchev et al., 2010; Maslikov \& Alyakina, 2013; Dmytryshyn \& Stefanyk, 2019).

В умовах близького існування котів з людьми, захворювання котів на хламідійні інфекції $є$ особливо небезпечним, оскільки захворювання $є$ зоонозом (Longbottom \& Coulter, 2003; Ksonz et al., 2010; Ksonz, 2012; Galatyuk et al., 2016).

Метою роботи було провести аналіз поширення хламідіозу, визначити епізоотологічні фактори, що сприяють прояву хламідіозу котів у місті Полтава та вивчити клінічні ознаки за хламідійної моноінфекціїі.

\section{Матеріал і методи досліджень}

Робота виконувалася у 2018-2020 роках в умовах навчальної лабораторії кафедри інфекційної патології, гігієни, санітарії та біобезпеки та науково-навчальновиробничої клініки ветеринарної медицини Полтавської державної аграрної академії. Епізоотичний аналіз щодо інфекційних хвороб котів у м. Полтава здійснювали, на основі підрахунку випадків звернень громадян із хворими котами, лікування хворих тварин. В окремих випадках досліджували хворих тварин, що лікувалися на інших клініках м. Полтави та зверталися за консультацією.

Особливу увагу приділяли вивченню клінічних ознак і патологоанатомічних змін за спонтанного прояву хламідіозу. Клінічні дослідження виконувалися загальноприйнятими методами, включаючи детальний анамнез. Діагноз на хламідіоз котів встановлювали комплексно, враховуючи результати анамнезу, епізоотологічні дані, типові клінічні ознаки, результати цитологічних досліджень.

Цитологічні дослідження проводили в умовах навчальної лабораторії кафедри інфекційної патології, гігієни, санітарії та біобезпеки. Для цього, відбирали матеріал із поверхні кон'юнктиви робили мазок, який фарбували за методом Романовського згідно до стандартної методики (Halánová et al., 2011). Після встановлення попереднього діагнозу, були відібрані зраз- 
ки матеріалу і відправлені до приватної лабораторії, м. Полтави для встановлення остаточного діагнозу. Власникам котів, 3 клінічними ознаками ураження очей, було рекомендовано здати проби для дослідження методом ПЛР до приватних лабораторій міста Полтави.

\section{Результати та їх обговорення}

У багатьох випадках інфекційні хвороби котів були спровоковані моно-інфекцією чи асоціацією збудників. Серед них важливе значення мають вірусні інфекції: herpesvirus, calicivirus. Серед бактеріальних Chlamidia та Mycoplasma.

За період 2018-2020 рік зустрічались такі інфекційні хвороби котів: панлейкопенія каліцивіроз, герпесвірусний ринотрахеїт, хламідіоз. Найбільша кількість досліджуваних котів, яким надавалася допомога, були безпорідними або помісними. Тому респіраторні хвороби найчастіше реєстрували у безпорідних котів. Вираженої чіткої сезонності не відмічалось, але більшу кількість випадків респіраторних хвороб реєстрували в осінньо-зимовий період року. За період січень 2018 р. - січень 2019 р. було поставлено діагноз на інфекційні хвороби 43 котам. Діагноз на панлейкопенію, каліцівірусну інфекцію, інфекційний ринотрахеїт встановлювали на основі клінічних ознак та експрестестів. Серед них, найбільша кількість зареєстрованих отримали діагноз “Каліцівіроз” - 22 випадок, що становить близько 51 \% від усіх хворих тварин з інфекційною патологією. У 11-ти тварин встановлений діагноз “панлейкопенія”, що відповідало 26 \%. Дещо нижчі показники вказували на захворюваність хламідіозу - шість випадків (14 \%), інфекційного ринотрахеїту - три випадки (7 \%) і один випадок інфекційного перитоніту (2\%).

У наступному році збір і аналіз епізоотологічних даних щодо хламідіозу котів оптимізували. При цьому, здійснювали підрахунок не лише кількості хворих на хламідіоз котів, а й реєстрацію асоційованих форм хламідіозу з каліцівірусною інфекцією, панлейкопені$є ю$, інфекційним ринотрахеїтом та інфекційним перитонітом котів. За аналогічний період у 2019-2020 році усього нараховано 48 випадків захворювання котів 3 інфекційними хворобами. Серед них 23 тварини 3 каліці вірусною інфекцією, чотири кота 3 пан лейкопенією, сім - з інфекційним ринотрахеїтом. Хламідіоз було виявлено у 14 котів. Це на вісім випадків (55 \%) більше, ніж у попередньому році. Дослідження на хламідійну інфекцію рекомендували також тваринам 3 патологію очей, але мали інший встановлений діагноз. Внаслідок проведених досліджень, кількість котів 3 хламідійною інфекцією зріс за рахунок асоціативного перебігу і становив 21 випадок. Інфекційний ринотрахеїт, асоційований з хламідіозом було встановлено у чотирьох тварин (18,5 \%). Від 2 тварин, $(8,6$ \%), що мали яскраві клінічні ознаки каліцівірусної інфекції, було виділено збудник хламідіозу. Асоціацію хламідіозу та панлейкопенії було зареєстровано у одного кота, що становить 4,9%. За інфекційного перитоніту наявність збудника хламідіозу не досліджували.

Клінічні ознаки вивчалися у котів, що мали гострий та підгострий прояв хламідіозу. При цьому, реєстрували хламідійну моноінфекцію.

У більшості випадків господарі пов'язували зараження тварин 3 контактами своїх улюбленців 3 іншими котами. Інкубаційний період хвороби тривав, згідно до даних анамнезу, від кількох днів до 2-3 тижнів.

На початку захворювання в усіх випадках реєстрували підвищення температури тіла на $1-2{ }^{\circ} \mathrm{C}$. Перші клінічні ознаки були мало специфічні: загальне пригнічення, зниження апетиту. У всіх тварин, за гострої хламідійної моноінфекції були ознаки серозного кон'юнктивіту (рис. 1).

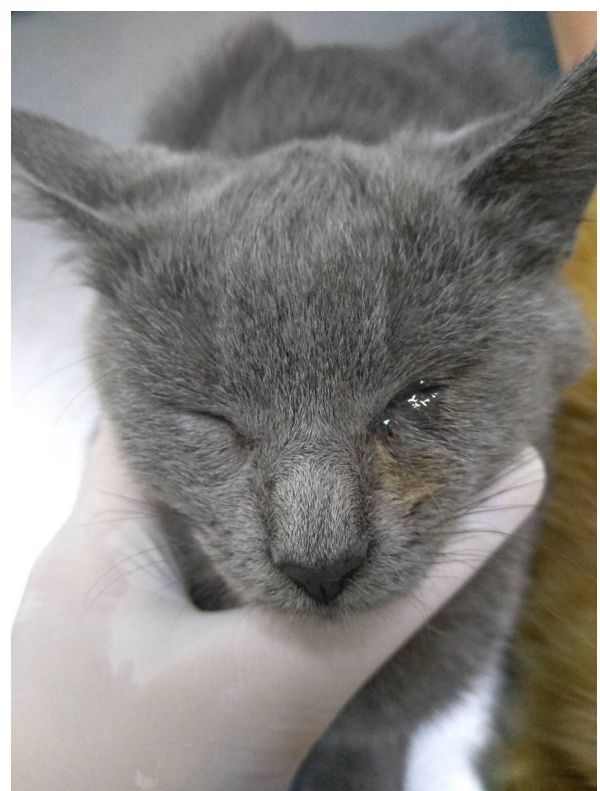

Рис. 1. Ознаки одностороннього кон'юнктивіту у кошеня за хламідіозу

Такий кон'юнктивіт був частіше одностороннім. Але у трьох котів за гострого хламідіозу виявляли двосторонній кон'юнктивіт (рис. 2).

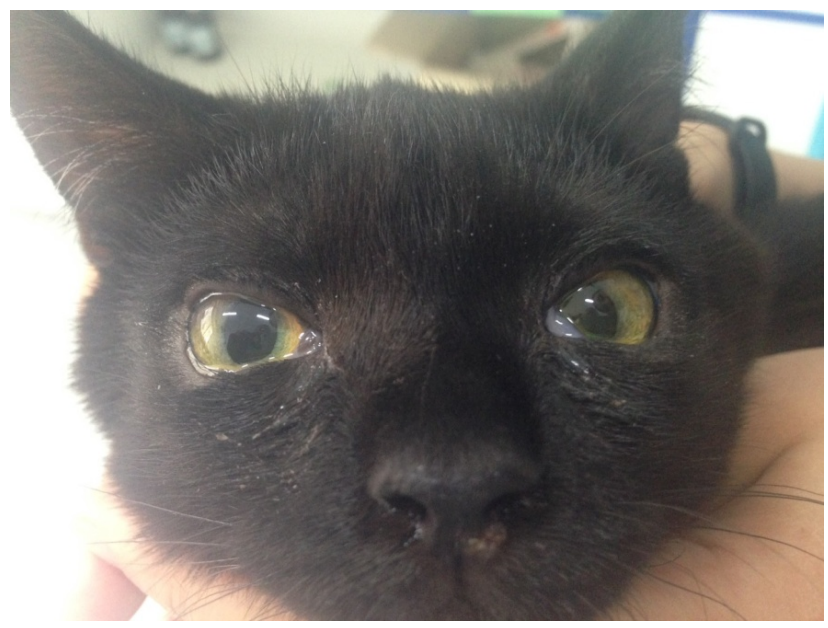

Рис. 2. Ознаки двостороннього серозного кон'юнктивіту за хламідіозу кота 
Згідно із даними анамнезу, початок захворювання у таких котів також характеризувався одностороннім запаленням кон'юнктиви. Впродовж тижня, у патологічний процес залучалося і друге око. Одночасно 3 серозним кон'юнктивітом розвивався серозний риніт. Кошенята за гострого перебігу повністю відмовлялися від їжі.

Дорослі кішки навіть на фоні незначного підвищення температури, та серозного кон'юнктивіту продовжували вживати їжу.

У котів, які потрапили на прийом за підгострого перебігу, окрім серозного кон'юнктивіту найбільш характерними були: випинання кон'юнктивальної оболонки через щілину ока (хемоз) і спазми верхньої і нижньої повік (блефароспазм) (рис. 3).

Із часом, внаслідок ускладнення процесів гнійною мікрофлорою (бактеріальною або вірусною), кон'юнктивіт продовжується у серозно-гнійний, а виділення з ока ставали інтенсивнішими, тягучими, коричневого кольору та набували неприємного запаxy.

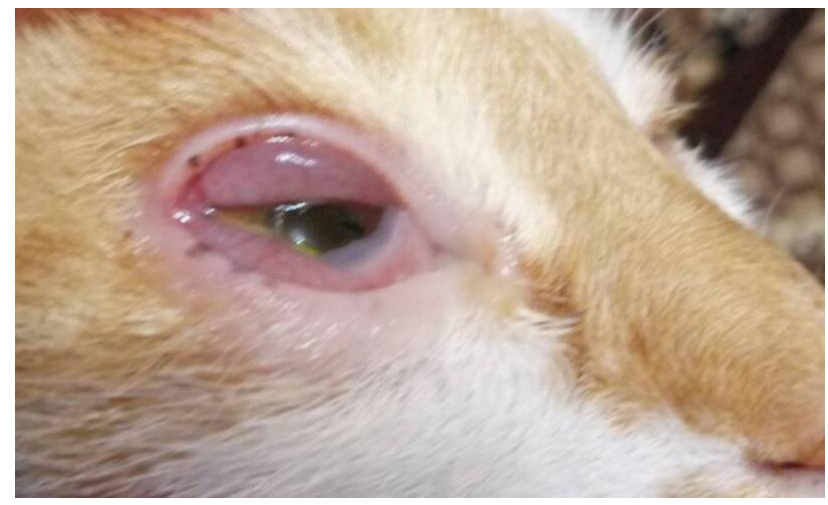

Рис. 3. Хемоз-характерна клінічна ознака за хламідіозу кота

За таких процесів різко змінювався і колір самої кон'юнктиви. Остання набувала яскраво-червоного (вишневого або цегляного) кольору. Більш інтенсивно забарвлені куточки ока. Внаслідок перенаповнення судин і венозного стазу у капілярах окремі судини ставали добре помітними (рис. 4).

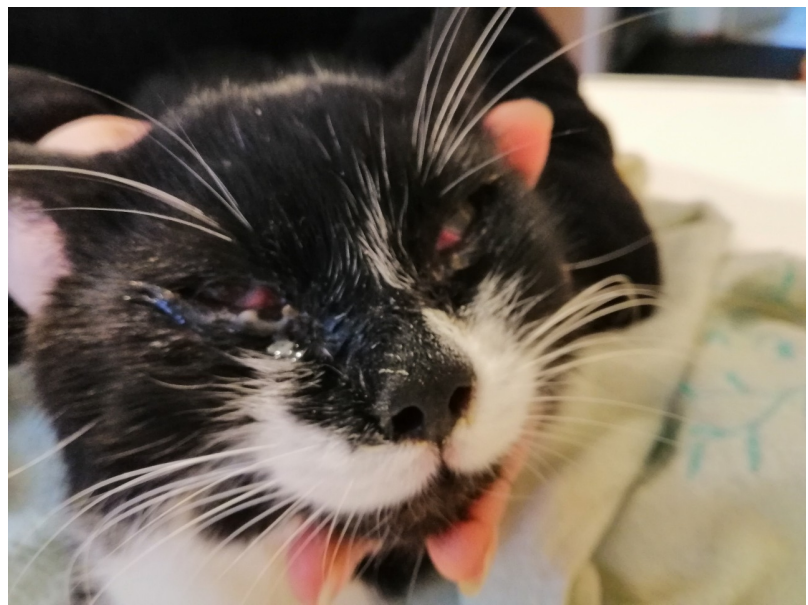

Рис. 4. Темно-червоний колір кон'юнктиви в кутках ока за хламідіозу
Хронічний перебіг супроводжувався ледь помітним забарвленням кон'юнктиви. Знижувалась інтенсивність виділень. Для таких процесів було характерно прикриття частини ока (іноді значної, за площею) третьою повікою та розвиток фолікулярного кон'юнктивіту (рис. 5).

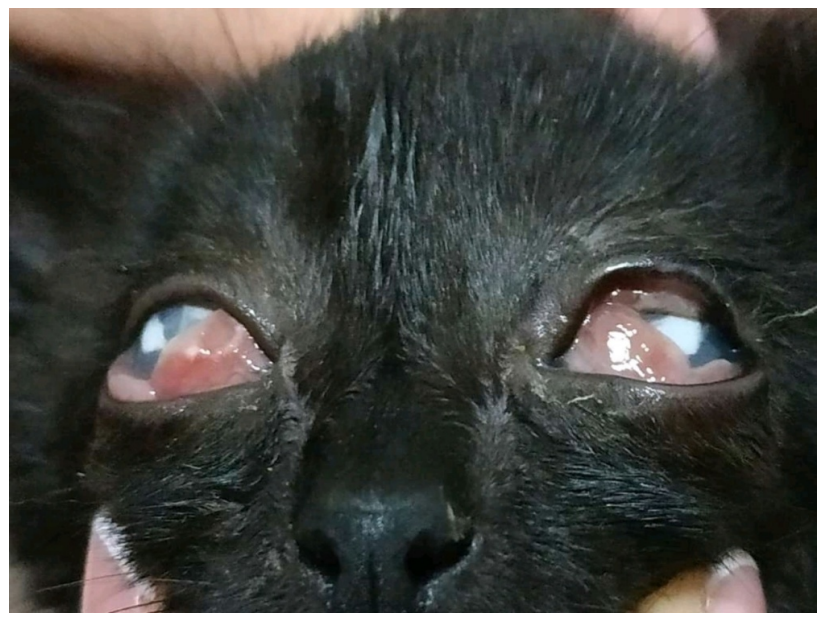

Рис. 5. Закриття ока третьою повікою за хламідіозу

В окремих випадках за відсутності лікування котів господарі змушені були звернутися на клініку за допомогою. Це відбувалося тому, що інтенсивні слизово-гнійні виділення не припинялися впродовж місяця. У таких тварин після кон'юнктивітів розвивалися бронхопневмонії (8 клінічні випадки) та порушення серцево-судинного ритму. У цих тварин реєстрували важке дихання, кашель, хрипи, сильне пригнічення.

Часто, на клініку ветеринарної медицини за допомогою зверталися власники розплідників. Сприйнятливими до хламідіозу є коти породи мейн-кун. Після в'язки з котом, клінічні ознаки проявляються у молодих кішок. Через 10-14 діб після в'язки господарі помічали прояви серозного кон'юнктивіту та риніту. У подальшому, серозні кон'юнктивіти ставали слизово-гнійними. До них додавалися розлади шлунковокишкового тракту: проноси, болючість черевної стінки, зниження апетиту. Також господарі відмічали порушення функції дихання: задишку під час тривалих рухів та сильний кашель. А саме дихання супроводжувалося інтенсивними хрипами.

За гострого перебігу, хламідіоз швидко поширювався у розпліднику. Після появи клінічних проявів хвороби у молодих кішок, у більшості випадків в подальшому реєстрували ознаки хвороби у кошенят. Спочатку підвищувалася температура. При підвищенні температури, кошенята ставали пригніченими i відмовлялися від корму.

У значної частини кішок захворювання протікало у латентній формі. Хворобу запідозрили власники тварини, які зверталися на клініку після народження нежиттєздатних кошенят чи абортів кішки.

Усі ці тварини були вагітними вперше. У таких випадках, клінічні ознаки за хламідіозу не були характерними. Іноді після в'язки із хворим плідником у кішки знижувався апетит, підвищувалася температура на $1-2{ }^{\circ} \mathrm{C}$. Як правило, швидко розвивається односто- 
ронній серозний кон'юнктивіт, який господарі не завжди помічали. Ці нехарактерні клінічні ознаки швидкоплинні; швидко стан хворої кішки покращувався. Пологи відбуваються без ускладнень, але кошенята народжувалися мертвими або нежиттєздатними. Загибель останніх відбувалася впродовж декількох діб.

У маленьких кошенят (1-2 тижня) виявляли неонатальний хламідійний кон'юнктивіт. Такий процес характерний для трансплацентарного зараження. Або, можливо, зараження кошенят відбувалося в процесі народження, при проходженні плода родовими шляхами хворої кішки.

У кошенят що народилися, клінічні ознаки хламідіозу проявлялися, щойно вони починали відкривати очі. Основними клінічними ознаками було ураження очей: набряки кон'юнктиви, іiі почервоніння та виділення із очей значної кількості коричневого гнійного ексудату із в'язкістю катару і як наслідок злипання повік та ускладнення у вигляді анкілоблефарону чи сімблефарону. Підщелепні, та інші лімфатичні вузли в ділянці голови суттєво збільшуються. Часто гній засихав біля носа та ротової порожнини, утворював кірочки. Вони заважали тварині дихати, тому кошенята часто кашляли, чхали, сопіли та намагалися звільнитися від кірочок за допомогою лапок. У більшості випадків, котенята відмовлялися смоктати кішку, вживати інші корми. Вони стрімко слабшали, їм було складно смоктати та жувати. Вони гинули на фоні наростаючої слабкості. Але, в одному гнізді частина кошенят, навіть 3 важкою формою не гинули, у них тривалий час реєстрували гнійні кон'юнктивіти та риніти.

У подальшому, за відсутності кваліфікованої допомоги, у інфекційний процесс залучаються й інші тканини ока. У кошенят часто розвивався гнійний панофтальміт (рис. 6).

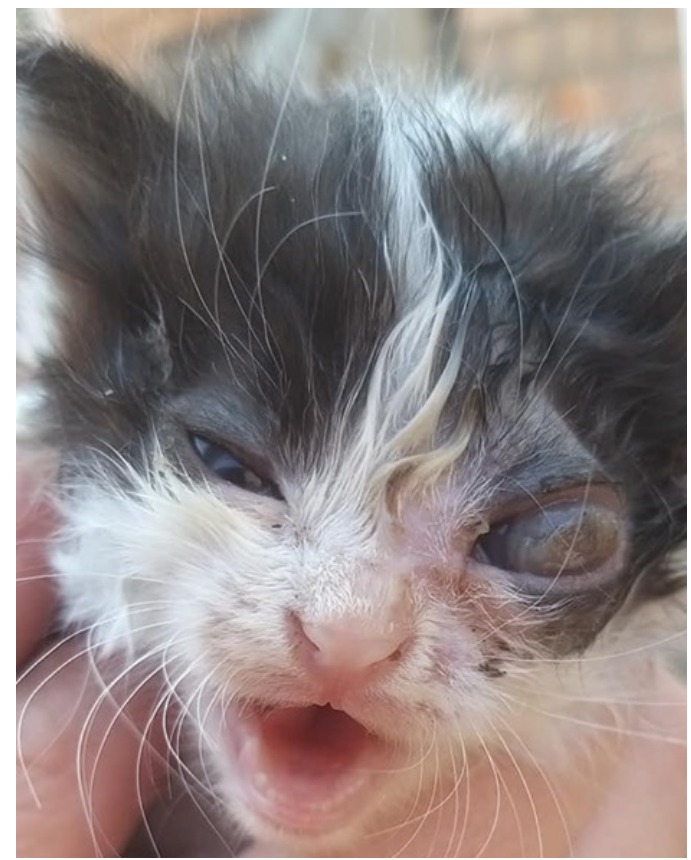

Рис. 6. Гнійний панофтальміт кошеня: неонатальний хламідійний кон'юнктивіт
Такі тварини важко піддавалися лікуванню та в подальшому суттєво відставали у рості та розвитку. В окремих випадках спостерігали розлади шлунковокишкового тракту. У двох випадках розвивалася бронхопневмонія.

В одному випадку у кота породи “Сфінкс" на передній лапі виявляли ознаки гострого хламідійного артриту. У тварини був досить виражений запальний набряк кінцівки. Припухлість була м'яка, розлита та дуже болюча. На уражену кінцівку тварина намагалася не опиратися.

За асоційованого прояву хламідіозу та інфекційного ринотрахеїту, в усіх випадках вражалися структури ока. Ці ураження могли бути різними, залежали від стадії інфекційного процесу (рис.7, 8).

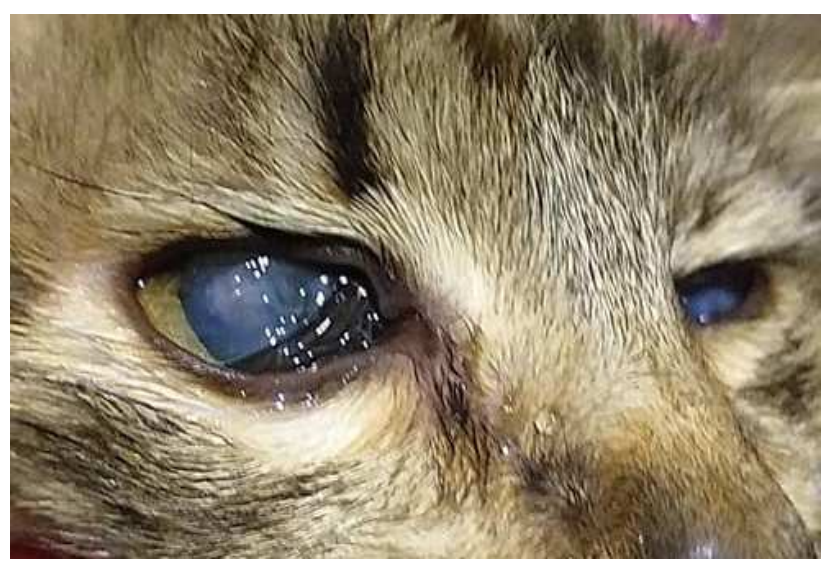

Рис. 7. Дифузний кератит у кота за асоційованого хламідіозу

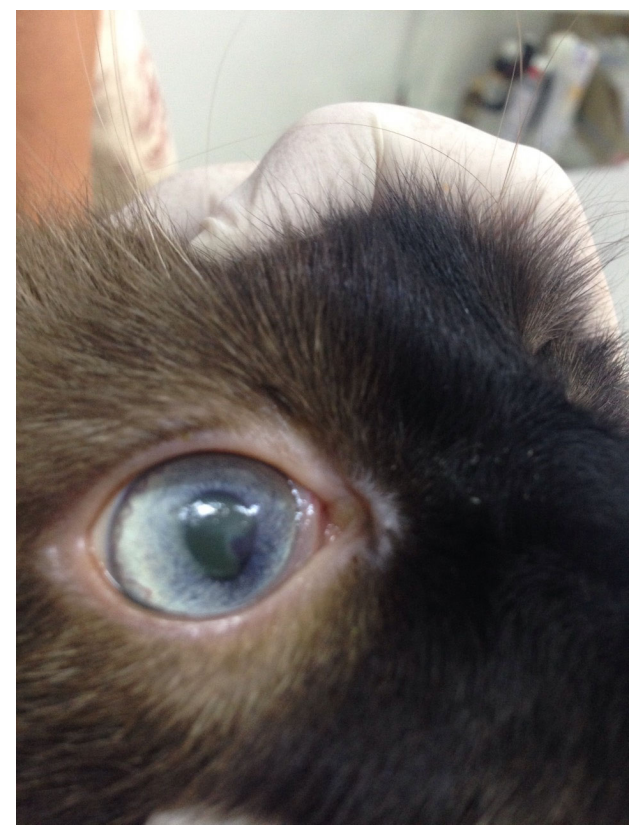

Рис. 8. Увеїт та зміна зіниці за асоційованого хламідіозу

\section{Висновки}

Хламідіоз котів у м. Полтава поширений, впродовж 2019-2020 року кількість котів хворих на хламідійну моно інфекцію збільшилася, у порівнянні 3 
попереднім і становила 14 випадків проти шести у попередньому році. У структурі інфекційних захворювань за дослідний період хламідійну моно інфекцію реєстрували у $68 \%$ котів, асоціацію хламідіозу з інфекційним ринотрахеїтом у $18,5 \%$, каліцівірусною інфекцією - 8,6 \%, з панлейкопенією - 4,9 \%. Найбільша кількість зареєстрованих котів мали гострий та підгострий перебіг хламідіозу. За гострого перебігу відбувалася підвищення температури, пригнічення та відмова від їжі. У більшості випадків гострого, підгострого та асоційованого хламідіозу вражалися структури ока. Розвивалися кон'юнктивіти, кератити, хемози, увеїти, запалення третьої повіки, зміни форми зіниці. У котів породи сфінкс виявляли гострі артрити передньої кінцівки. Латентний перебіг супроводжувався абортами. Аборти реєстрували у молодих кішок. $\mathrm{У}$ тварин старше чотирьох років частіше виявляли мертвонароджених та слабких кошенят. Неонатальний хламідіоз проявлявся кон'юнктивітами, кератитами, злипанням повік, ускладненнями у вигляді анкілоблефарону чи сімблефарону; панофтальмітами та затримкою росту. Частина ураженого приплоду гинула впродовж перших трьох діб після народження.

\section{References}

Dmytryshyn, O., \& Stefanyk, V. (2019). Influence of some etiological factors on development of gynecological patholo-gy and infertility of cats. Scientific Messenger of LNU of Veterinary Medicine and Biotechnologies. Series: Veterinary Sciences, 21(94), 6673. doi: $10.32718 /$ nvlvet9412.

Galatyuk, O. Y., Peredera, O. O., Lavrinenko, I. V., \& Zhernosik, I. A. (2016). Infekcijni xvoroby kotiv. Navchalnyj posibnyk (in Ukrainian).

Halánová, M., Sulinova, Z., Cislakova, L., Trbolova, A., Palenik, L., Weissova, T., Halan, M., Kalinova, Z., \& Holickova, M. (2011). Chlamydophila felis in cats are the stray cats dangerous source of infection. Zoonoses and Public Health, 58(7), 519-522. doi: 10.1111/j.1863-2378.2011.01397.x.

Ksonz, I. M. (2012). Xlamidiozy tvaryn: [monografiya], Poltava, Oriyana (in Ukrainian).

Ksonz, I. M., Civenko, T. M., \& Lobov, A. V. (2010). Epizootychnyj stan shhodo xlamidijnoyi infekciyi u Xarkivskomu zooparku. Problemy' zooinzheneriyi ta veterynarnoyi medycyny, 22(3), 119-122 (in Ukrainian).

Lisova, V., \& Savchenko, A. (2017). Histological changes in cats at Chlamydiosis. Scientific Messenger of LNU of Veterinary Medicine and Biotechnologies. Series: Veterinary Sciences, 19(78), 158-161. doi: $10.15421 /$ nvlvet7832.

Longbottom, D., \& Coulter, L. J. (2003). Animal chlamydioses and zoonotic implications. J Comp Pathol., 128(4), 217-244. doi: 10.1053/jcpa.2002.0629.

Lyubeczkyj, V. J., \& Provalova, O. P. (2011). Poshyrenist xlamidij ta mikoplazm pry xvorobax reproduktyvnoyi systemy' u dribnyx tvaryn. Scientific Messenger LNUVMBT im. S. Z. Gzhyczkogo, 13(4(50), 253256 (in Ukrainian).

Martynyuk, O. G. (2015). Osobly`vosti zastosuvannya imunotropny`x preparativ za likuvannya sobak i kotiv/Naukovo-texnichny ’ byuleten ' $\mathrm{NDCz}$ biobezpeky' ta ekologichnogo kontrolyu resursiv APK, 3 (in Ukrainian).

Maslikov, S. M., \& Alyakina, M. A. (2013). Xlamidioz ochej $\mathrm{u}$ bezprytulnyx kotiv $\mathrm{m}$. Dnipropetrovs`k. Scientific Messenger LNUVMBT im. S. Z. Gzhyczkogo, 15(3(57), 187-192 (in Ukrainian).

Pantchev, A., Sting, R., Bauerfeind, R., Tyczka J., \& Sachse, K. (2010). Detection of all Chlamydophila and Chlamydia spp. of veterinary interest using species-specific real-time PCR assays. Comp Immunol Microbiol Infect Dis, 33(6), 473-484. doi: 10.1016/j.cimid.2009.08.002.

Romanyshyna, Y. R., Skrypnyk, V. H., \& Skrypnyk, A. V. (2012). Deya ki aspekty khlamidioziv sviys'kykh neproduktyvnykh tvaryn ta ptakhiv [Some aspects of Chlamydiosis of unproductive domestic animals and birds]. Visnyk Bilocerkivskogo derzhavnogo agrarnogo universytetu - Bulletin of Bila Cerkva State Agrarian University, 10(99), 5-8 (in Ukrainian).

Sachse, K., Bavoil, P. M., Kaltenboeck, B., Stephens, R. S., Kuo, C. C., Rossello-Mora, R., et al (2015). Emendation of the family Chlamydiaceae: proposal of a single genus, Chlamydia, to include all currently recognized species. Syst Appl Microbiol, 38(2), 99103. doi: 10.1016/j.syapm.2014.12.004.

Stavisky, J., Brennan, M., Downes, M., \& Dean, R. (2012). Demographics and economic burden of un-owned cats and dogs in the UK: results of a 2010 census. BMC Vet Res., 8(1), 63. doi: 10.1186/1746-6148-8-163.

Sykes, J. E. (2005). Feline chlamydiosis. Clin Tech Small Anim Pract, 20(2), 129-134. doi: 10.1053/j.ctsap.2004.12.018.

Wu, S. M., Huang, S. Y., Xu, M. J. et al. (2013). Chlamydia felis exposure in companion dogs and cats in Lanzhou, China: a public health concern. BMC Vet Res, 9, 104. doi: 10.1186/1746-6148-9-104. 